\title{
RENAL OSMOLAL OUTPUT OF PATIENTS WITH ACUTE TRAUMATIC PARAPLEGIA
}

\author{
By John A. D. Settle, M.Phil., M.R.C.S., L.R.C.P., D.A. \\ Spinal Injuries Centre, Pinderfields General Hospital, Wakefield
}

\section{INTRODUCTION}

CHRONIC renal failure is a well-known and common complication, accounting for one-third of the deaths of patients with traumatic paraplegia (Bors \& Comarr, I97I). By contrast, acute renal failure would seem to be a rare complication. A careful search has failed to reveal any publication on this subject. Furthermore, out of approximately 250 patients admitted during the past ten years to the Leeds Regional Spinal Unit with acute traumatic paraplegia, the early complication of acute renal failure has been diagnosed and treated on only one occasion.

\section{CASE HISTORY}

A 36-year-old man was knocked off his bicycle and run over by a motor vehicle. He sustained multiple injuries, including fractures of the skull, right clavicle, right scapula, right humerus and the left fifth rib. The man was paraplegic as a result of fracture dislocations of the upper thoracic vertebrae producing transection of the spinal cord at the level of $D_{3}$. After initial treatment at a large general hospital, he was transferred to the Regional Spinal Unit, 24 hours after the accident.

On admission he was obviously suffering from effects of oligaemia and hypoxia. An infusion of blood and dextran, monitored by measurement of the central venous pressure, corrected the oligaemia but cyanosis could be prevented only by continuous oxygen therapy. Within a few hours of admission it was necessary to perform a tracheostomy and institute positive pressure ventilation of the lungs. At this time, blood urea was $107 \mathrm{mg}$. per cent.; and $\mathrm{K} 5.4 \mathrm{mEq}$./1. Twenty-four hours later the blood urea had risen to $\mathrm{I} 88$ mg. per cent. and the $\mathrm{K}$ to $7.4 \mathrm{mEq}$./1. After intravenous insulin and glucose to lower the hyperkalaemia, peritoneal dialysis was commenced. Catheterisation of the bladder at this time produced $350 \mathrm{ml}$. of urine.

The dialysis was successful in preventing the blood urea from rising above $240 \mathrm{mg}$. per cent. and the $\mathrm{K}$ above $6.0 \mathrm{mEq}$./1. during the following few days. It was never possible to achieve adequate expansion of the left lung and the patient died in respiratory failure six days after the accident.

Acute Renal Failure. This can be produced by either prolonged and severe renal ischaemia (Brun, 1954) or by the nephrotoxic action of haem compounds released from damaged haemoglobin (Shen, et al., 1943) and myoglobin (Bywaters, I944). As the resuscitation of severely injured patients has improved, with more blood being given at an earlier stage of the treatment, so the incidence of renal failure due to gross oligaemia has declined (Parsons, I97I). However, when extensive tissue damage has occurred, apparently adequate resuscitation does not preclude the possibility of acute renal failure (Cason, 1966). Indeed, in those patients whose kidneys have failed following trauma, the occurrence of extensive tissue damage has been a frequent and ominously significant finding (Loughridge, 
et al., 1960). Because these patients are also in a state of hypercatabolism (Parsons, et al., I96I), it follows that if renal failure does occur, then uraemia will develop rapidly with the blood urea level rising by as much as Ioo $\mathrm{mg}$. per cent. per day. In a study of patients with severe burns, the author has shown that examination of the urine output is more reliable than observing the progress of uraemia in predicting the outcome of impaired renal function and in deciding whether to institute dialysis (Settle, I97I). There are two reasons for this opinion. First, it is possible for a hypercatabolic patient to have a blood urea level of $200 \mathrm{mg}$. per cent., 48 hours after severe trauma, resulting from impaired renal function which need not necessarily proceed to renal failure. Secondly, in such a patient, it may be advisable to administer a solute diuretic during the first 12 hours in an attempt to prevent renal failure. In general it can be said that in the diagnosis and treatment of acute disorders of renal function, there is no substitute for the examination of the hourly urine output to determine the volume and concentration of the urine and to detect the presence of haem compounds.

Renal Osmolal Output. The osmotic concentration of the body fluid, which in normal health is $290 \pm \mathrm{IO} \mathrm{mOs}$. $/ \mathrm{kg}$. water, is maintained by the renal excretion of solute (or osmoles) together with a variable amount of water. The excretion of solute is obligatory if uraemia is to be prevented while the excretion of water is partly obligatory and partly facultative. The total solute or osmolal load to be excreted from an average normal adult on a normal diet is of the order of 1200 mOsm. per day (Gamble, 1958). The maximum urine concentration usually achieved is about $1000 \mathrm{mOsm} . / \mathrm{kg}$. so, if the solute-free water intake is restricted then the urine volume can diminish to a minimum of $1200 \mathrm{ml}$. per day, an average of $50 \mathrm{ml}$. per hour. In these circumstances, the administration of solute-free water will be followed by an increase in urine volume and an inversely proportional decrease in urine concentration. If sufficient water is given, the urine concentration will fall below $290 \mathrm{mOs} . / \mathrm{kg}$., which means that a water diuresis will occur. If, on the other hand, water is given in an isotonic solution, the solute of which cannot be metabolised (e.g. 0.9 per cent. Sodium Chloride Solution) then, although the urine volume will increase, the total osmolal output will also increase and water diuresis will not be possible.

It has been reported (Joeks et al., I957) that normal subjects who have undergone prolonged and drastic restriction of dietary protein and sodium can achieve a daily renal osmolal output as low as $400 \mathrm{mOs.} \mathrm{This} \mathrm{osmolal} \mathrm{load} \mathrm{could} \mathrm{be} \mathrm{elimi-}$ nated in $400 \mathrm{ml}$. or urine of concentration $1000 \mathrm{mOs} . / \mathrm{kg}$., an average of $\mathrm{I} 7 \mathrm{ml}$. per hour. Many clinicians accept $25 \mathrm{ml}$. per hour of concentrated urine as evidence of adequate renal function even though this volume could contain no more than one-half of the average hourly osmolal load if the total daily load is at the normal level of I 200 mOs. It is evident, therefore, that any meaningful consideration of the adequacy of urine output must take into account not only the volume and concentration of the urine but also the size and metabolic status of the patient.

Osmolal Output of Patients with Acute Traumatic Paraplegia. Up to the moment of injury, most patients have been taking a normal diet and have been in a state of normal metabolism. On this basis, the osmolal load immediately after the injury should be similar to that of a normal subject and could be estimated from knowledge of the patient's weight. After injury, the osmolal load will be 
decreased by fasting and decreased by extra-renal solute loss from the gastrointestinal tract, in external haemorrhage, and in tissue fluid lost from the body. The load will be increased by intravenous therapy and by the hypercatabolism which is part of the metabolic response to trauma. Obviously, the product of these conflicting factors will vary from patient to patient but a useful base line is afforded by the measurement of the renal osmolal output in patients with acute traumatic paraplegia uncomplicated by severe trauma or intensive resuscitation.

The Figure shows the results of a study of five such patients in which the daily renal osmolal output in $\mathrm{mOs} . / \mathrm{kg}$. of body weight has been plotted against time in

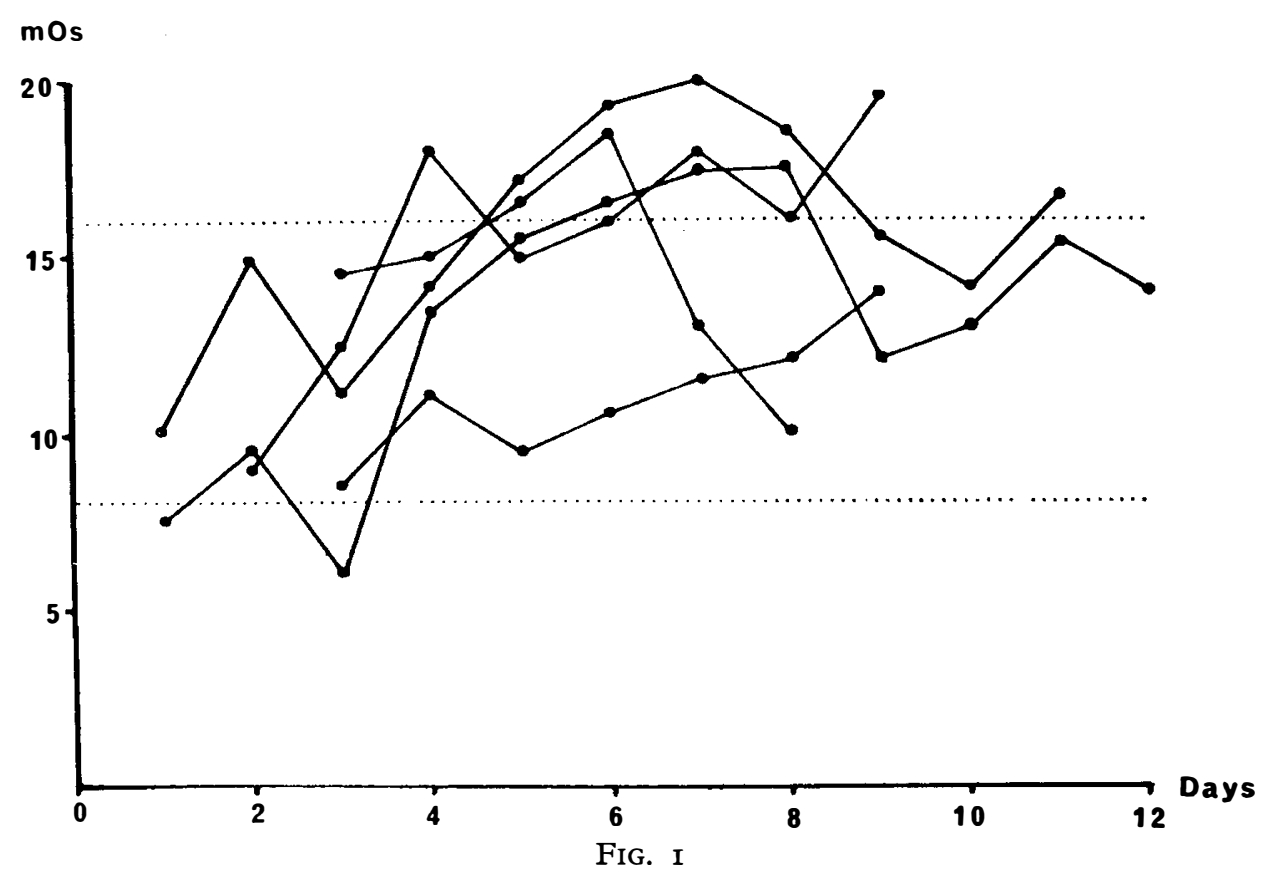

Daily renal osmolal output, in milliosmoles per kilogram body weight, of five patients with acute traumatic paraplegia.

days from the occurrence of the injury. After discarding the initial bladder contents, the daily output of urine was collected and the osmolality measured by a depression of freezing point method.

The upper reference line indicates the average normal osmolal output of about I6 mOs./kg. body weight per day. An average sized adult could excrete this osmolal output in about $50 \mathrm{ml}$. per hour of highly concentrated urine. The lower line indicates the output which would be excreted in $25 \mathrm{ml}$. per hour of highly concentrated urine, an obviously inadequate flow rate to clear the osmolal load of any of these patients. After the first few days, an increase could be seen in the renal osmolal output which probably reflects the increased osmolal intake following the return to a normal diet. Otherwise, the results are quite unremarkable and simply indicate that a patient with acute traumatic paraplegia can be expected to produce at least the same osmolal load as a normal subject. 
Post-traumatic Antidiuresis. One of the features of the metabolic response to trauma is the continued production of antidiuretic hormone (Le Quesne \& Lewis, 1953). In these circumstances, a water diuresis is not possible and the administration of large quantities of solute-free water will lead to water intoxication (Eisen \& Lewis, 1954). It does not follow, however, as is sometimes assumed, that for a day or two after trauma a patient will necessarily be oliguric. Indeed, as pointed out by Moore (1960) when antidiuretic hormone activity is maximal there is a linear relationship between total solute excretion and urine flow. It is because of this that a solute diuretic such as Mannitol is able to increase urine flow even to the extent of producing dehydration. What can be assumed is that the urine produced during the first 48 hours following trauma will be concentrated urine unless either the volume output is greatly increased or renal failure has occurred. For example, if $50 \mathrm{ml}$. per hour of urine at a concentration of $1000 \mathrm{mOs}$. $/ \mathrm{kg}$. is adequate to clear the osmolal load of an injured patient, then $200 \mathrm{ml}$. per hour at a concentration of $500 \mathrm{mOs} . / \mathrm{kg}$. indicates that a solute diuresis is occurring while $50 \mathrm{ml}$. per hour at a concentration of $300 \mathrm{mOs} . / \mathrm{kg}$. indicates non-oliguric renal failure.

Assessment of Renal Function. In the management of acute traumatic paraplegia there are, of course, very good reasons for avoiding early catheterisation of the bladder in the majority of patients. However, if there are features of the injury which raise the possibility of renal function being impaired, for example, extensive or crushing injuries, oligaemia or hypoxia, then the measurement of the hourly urine output becomes mandatory.

The best index of urine concentration is afforded by the measurement of its osmolality. The determination of specific gravity, although commonly performed, can become very misleading if large molecules such as glucose, protein, or dextran are present in the urine and a more satisfactory alternative to osmolality is the comparison of the urine urea level with that of plasma. A U/P urea ratio of less than I4 in the presence of oliguria can be taken to indicate renal impairment (Perlmutter et al., 1959).

When, as in the case history reported earlier, the urine output of an injured patient is unknown for the first 48 hours after the injury, the diagnosis of renal failure is usually made quite suddenly. Unless requested as urgent, blood urea levels, etc., are often not reported until the end of the working day at which time specialist advice may not be easily obtainable. By contrast, the monitoring of the hourly urine volume and concentration permits a picture to gradually emerge which can, on some occasions, confirm a diagnosis of renal failure within 24 hours of the injury and on other occasions indicate the need for therapeutic action to prevent renal failure from developing. There can be no doubt that this orderly and thoughtful process of investigation is preferable to the sudden awareness of a crisis situation.

\section{SUMMARY}

Acute renal failure is a rare complication in patients with acute traumatic paraplegia but should be considered as a possibility when there is severe tissue damage or considerable blood loss in the patient. A case is described in which the diagnosis of acute renal failure was made on the basis of azotaemia and hyperkalaemia 48 hours after the injury. It is suggested that if the urine output had been 
frequently examined during this period it is likely that renal impairment would have been diagnosed much earlier and attempts could have been made to abort renal failure. The determinants of an 'adequate' urine output in both normal subjects and injured patients (particularly those with acute traumatic paraplegia) are discussed at length.

Acknowledgments. I am grateful to Dr. J. B. Cook, M.D., F.R.C.P., Consultant Neurologist in charge of the Leeds Regional Spinal Unit, for permission and encouragement to investigate the renal function of patients under his care.

\section{REFERENCES}

Bors, E. \& ComarR, A. E. (I971). Neurological Urology, p. 352. Basel: S. Karger.

BRUn, C. (1954). Acute Anuria. Copenhagen.

BYwaters, E. G. L. (I944). Ischemic muscle necrosis, crushing injury, traumatic edema, the crush syndrome, traumatic anuria, compression syndrome: A type of injury seen in air raid casualties following burial beneath debris. F. Amer. Med. Asso. 124, I 103.

Cason, J. S. (1966). Treatment of renal failure. Transactions of the Second International Congress on research in burns, Edinburgh 20th-24th Sept. 1965, p. I2 (Eds. A. B. Wallace \& A. W. Wilkinson). Edinburgh: Livingstone.

EIsEN, V. D. \& LEwIS, A. A. G. (I954). Antidiuretic activity of human urine after surgical operations. Lancet, 2, 36r.

Gamble, J. L. (1958). Extracellular Fluid, 6th Edn. Cambridge, Massachusetts: Harvard University Press.

Joekes, A. M., Mowbray, J. F. \& Dormandy, K. (1957). Oliguria with urine of 'fixed' specific gravity. Lancet, 2, 864 .

Le Quesne, L. P. \& Lewis, A. A. G. (I953). Post-operative water and sodium retention. Lancet, $\mathbf{I}, \mathrm{I} 53$.

Loughridge, L. W., Milne, M. D., Shackman, R. \& Wootton, I. D. P. (I960). Clinical course of uncomplicated acute tubular necrosis. Lancet, $\mathbf{I}, 35 \mathrm{I}$.

MOORE, F. D. (I960). Solute diuresis as a therapeutic aspect of the burn physiology. p. IOI. Proceedings of the Ist Int. Congr. in Burns, Bethesda, Maryland, I9th to 22nd Sept. 1960. Ed. C. P. Artz. Philadelphia: F. A. Davis Co.

Parsons, F. M. (I97I). Director, Renal Research Unit, Leeds General Infirmary. Personal communication.

Parsons, F. M., Hobson, S. M., Blagg, C. R. \& McCracken, B. H. (I96I). Optimum time for dialysis in acute renal failure. Lancet, $\mathbf{I}, \mathrm{I} 29$.

Perlmutter, M., Grossman, S. L., Rothberg, S. \& Dobkin, G. (1959). Urine-serum urea nitrogen ratio (simple test of renal function in acute azotemic oliguria). f. Amer. Med. Ass., 170, 1533 .

SetTLE, J. A. D. (I97I). Urine output following severe burns. M.Phil. Thesis (Leeds).

Shen, S. C., HAM, T. H. \& Fleming, E. M. (I943). Studies on the destruction of red blood cells. III. Mechanism and complications of hemoglobinuria in patients with thermal burns. New Engl. F. Med. 229, 701 . 